\title{
EDUCAÇÃO INFANTIL EM TEMPOS DE PANDEMIA: QUANDO UMA MÁQUINA DO TEMPO APROXIMA AS DISTÂNCIAS
}

\author{
Cláudia Vasconcellos Nogueira da Gama ${ }^{\mathrm{i}}$ \\ Maria Marta de Andrade Cerqueiraii \\ Patrícia da Paz Zampieriii
}

\begin{abstract}
Resumo: Este artigo narra experiências vividas com crianças da Educação Infantil, de uma escola da rede privada do Rio de Janeiro, durante o período de afastamento social provocado pela covid-19. Baseamo-nos no conceito das múltiplas linguagens, de Malaguzzi (1999); na pedagogia de Freinet (1973), pautada na cooperação, na comunicação e na afetividade; e na concepção de sujeito histórico-social de Vygotsky (1984) para elaborar propostas significativas que propiciam a manutenção dos vínculos afetivos nesse período. Com essa observação participante, concluímos que os encontros virtuais com crianças pequenas estão longe de ser o ideal, mas foi através deles que conseguimos valorizar as vozes das crianças, o imaginário criativo e o brincar como ferramentas de mediação de aprendizagem.
\end{abstract}

Palavras-chave: Educação Infantil, Imaginação, Múltiplas Linguagens, Criação e Mídia Digital.

\section{EARLY CHILDHOOD EDUCATION IN TIMES OF PANDEMIC: WHEN A TIME MACHINE APPROACHES DISTANCES}

\begin{abstract}
This article narrates experiences with children in Early Childhood education, from a Rio de Janeiro's private school, during the period of social withdrawal caused by COVID-19. We are based on the concept of multiple languages, by Malaguzzi (1999); Freinet's pedagogy (1973), based on cooperation, communication and affection; and Vygotsky's (1984) conception of the social-historical subject to think of meaningful proposals, capable of maintaining the affective bonds in this period. With this participant observation, we concluded that virtual meetings with young children are far from ideal, but it was through them that we were able to value children's voices, their creative imaginary and the act of playing as mediation tools for learning.
\end{abstract}

Keywords: Child Education, Imagination, Multiple Languages, Creation and Digital Media.

\section{Primeiras palavras}

A criança é feita de cem. A criança tem cem mãos, cem pensamentos, cem modos de pensar, de jogar e de falar. Cem, sempre cem modos de escutar as maravilhas de amar.

Cem alegrias para cantar e compreender. Cem mundos para descobrir. Cem mundos para inventar.

Cem mundos para sonhar. A criança tem cem linguagens (e depois, cem, cem, cem), Licença Creative Commons Atribuição Não Comercial-Compartilha Igual (CC BY-NC-4.0), que permite uso, distribuição e reprodução para fins não comerciais, com a citação dos autores e da fonte original esob a mesma licença. 


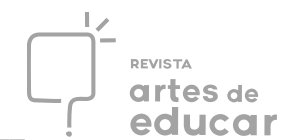

mas roubaram-lhe noventa e nove.

A escola e a cultura separam-lhe a cabeça do corpo.

Dizem-lhe: de pensar sem as mãos, de fazer sem a cabeça, de escutar e de não falar,

De compreender sem alegrias, de amar e maravilhar-se só na Páscoa e no

Natal.

Dizem-lhe: de descobrir o mundo que já existe e, de cem,

roubaram-lhe noventa e nove.

Dizem-lhe: que o jogo e o trabalho, a realidade e a fantasia, a ciência e a imaginação,

O céu e a terra, a razão e o sonho, são coisas que não estão juntas. Dizem-lhe: que as cem não existem. A criança diz: ao contrário, as cem existem.

Loris Malaguzzi

Entendemos que a criança possui muitas formas de se conectar com o mundo, como o fragmento em epígrafe de Malaguzzi inspira a pensar. É através da exploração do que a cerca que ela vai desenvolvendo e construindo seus valores. Em seu texto "As cem linguagens das crianças" (MALAGUZZI, 1999, p. 5), o referido autor traz à tona uma crítica sobre a racionalidade técnica, que marca as propostas educativas, principalmente na Educação Infantil. Ele nos atenta sobre a potência transgressora das crianças, com uma perspectiva crítica ao nosso mundo. Nesse sentido, é indispensável que a escola se ofereça como espaço de potência e não de cerceamento. $\mathrm{O}$ ambiente escolar precisa propiciar a escuta, o diálogo, a investigação, a troca, a brincadeira e a utilização de diversas linguagens como forma de expressar ideias, opiniões e visões de mundo.

Sendo assim, iniciamos este relato de experiência trazendo esta importante reflexão sobre o ato de educar. Ato, este, voltado aos princípios das relações afetivas, cognitivas e sociais, pelos quais a criança seja capaz de se relacionar consigo, com o outro e com o mundo; que seja provocada a desejar inventar, levantar suas hipóteses, descobrir, criar, sem medo de errar, construindo saberes ao longo de toda a sua trajetória. Defendemos a ideia de uma escola que se preocupa com a formação de sujeitos capazes de viver em uma sociedade democrática: justa, cooperativa e solidária. Isto é, uma sociedade onde a diferença, a convivência pacífica e o respeito a todos os seres vivos sejam pontos fundamentais na construção de suas subjetividades.

Vale ressaltar que a experiência na Educação Infantil envolve todos os sentidos através do corpo, com situações diferentes que as crianças vivem no ambiente, com os objetos e com outras pessoas, provocando o tocar, o afetar, o sentir. Segundo Jorge Larrosa Bondía (2002), o saber da experiência é um saber construído a partir da relação entre os sujeitos e os 
acontecimentos. Assim, a criança vai construindo novos saberes, com ações significativas que atravessam suas vidas de forma marcante.

Diante disso, o cotidiano escolar também precisa ser organizado de forma a garantir um ambiente lúdico e seguro, que favoreça a descoberta do mundo e as práticas investigativas, respeitando sempre o olhar e o ritmo próprios de cada criança. As atividades precisam ser planejadas, de acordo com cada grupo ou criança, respeitando seus desejos e interesses, priorizando as brincadeiras, a fantasia e a imaginação. Esses são recursos valiosos para Educação Infantil. É através da imaginação criativa, direcionada para as ações educativas, com ênfase nas narrativas orais, que podemos integrar diferentes áreas do conhecimento, abrindo diversos caminhos ou possibilidades para novas evidências e aprendizagens significativas.

Entendemos que "o ambiente é visto como algo que educa a criança” (GANDINI, 2016, p. 148) e este espaço precisa passar por mudanças frequentes feitas pelas crianças, que vão dando forma e significados de acordo com suas necessidades. A prática no cotidiano traz a exploração fazendo "com que o seu ambiente se torne rico em possibilidades, onde a forma de expressão deva ser percebida em suas múltiplas linguagens” (SIMONE, 2020, p. 19).

No entanto, no ano de 2020, a possibilidade das (con)vivências e aprendizagens fomentadas no espaço escolar infelizmente foi de repente interrompida pela chegada da pandemia de covid-19, pegando todos de surpresa. O cenário de afastamento social e de escolas fechadas por tempo tão prolongado não foi pensado pela grande maioria da população. $\mathrm{O}$ sentimento que nos assolou foi de angústia e de incertezas, ainda mais potencializado quando refletíamos sobre o difícil cenário da educação.

O cenário caótico que se apresentou, além de incertezas, também nos trouxe considerações sobre os tempos em que vivemos. Boaventura de Sousa Santos (2020), em sua mais atual obra, "A cruel pedagogia do vírus", pontua algumas lições que podemos aprender com a pandemia do novo coronavírus, principalmente quando observamos a questão socioeconômica e as desigualdades em nossa sociedade. A população mais pobre foi a que mais esteve vulnerável nesse período, pois, muitas vezes, mal possui acesso básico à água. Nesse sentido, nunca se fez tão urgente repensar o modelo de desenvolvimento, baseado nas práticas neoliberais. Segundo Boaventura de Sousa Santos:

[...] uma das características essenciais deste modelo é a exploração sem limites dos recursos naturais. Essa exploração está a violar de maneira fatal o lugar da humanidade no planeta Terra. Esta violação traduz-se na morte desnecessária de muitos seres vivos da Mãe Terra, nossa casa comum, como defendem os povos indígenas e camponeses de todo o mundo, hoje secundados pelos movimentos ecologistas e pela teologia ecológica. Essa 
violação não ficará impune. As pandemias, tal como as manifestações da crise ecológica, são a punição que sofremos por tal violação. Não se trata de vingança da Natureza. Trata-se de pura auto-defesa. O planeta tem de se defender para garantir a sua vida. A vida humana é uma ínfima parte $(0,01 \%)$ da vida planetária a defender. (SANTOS, 2020, p. 23)

Ailton Krenak também faz um apontamento muito relevante no que diz respeito à nossa relação exploratória com a natureza. Se esta tem sido "assaltada de uma maneira tão indefensável”, que possamos ser "capazes de manter nossas subjetividades, nossas visões, nossas poéticas sobre a existência" (KRENAK, 2019, p. 32-33). Portanto, ponderar sobre os caminhos da educação em tempos tão sombrios, como o de pandemia, é contribuir para o debate sobre o desenvolvimento de nossa sociedade. Nunca a educação crítica se fez tão necessária quanto nos tempos atuais. Uma educação problematizadora, que ultrapassa as barreiras da doutrinação, que transcende a barreira da racionalidade técnica, que respeita as diferentes formas de perceber e sentir o mundo e que ensina a olhar para a "Mãe Terra" (SANTOS, 2020, p. 23) com respeito, fazendo-nos compreender que somos parte dela.

Considerando todo o exposto, apresentamos este relato sobre experiências vividas com crianças da Educação Infantil em tempos de afastamento social, decorrentes da pandemia de covid-19. No presente texto, propomos apresentar como nós, professoras e coordenadora de uma escola de Educação Infantil, da rede privada, na zona sul da cidade do Rio de Janeiro, percebemo-nos diante desse desafio e como procuramos buscar novas possibilidades para manter vínculos afetivos com nossa comunidade escolar e, de certa forma, sermos unidade no enfrentamento dessa difícil crise social e de saúde global.

Vale ressaltar que a pandemia e a imposição do afastamento social também reverberaram na forma de pesquisar. Nesse atual contexto, tornou-se necessário recontextualizar algumas metodologias para que fosse viável continuar produzindo pesquisas relevantes e atuais para o campo educacional. Assim sendo, a metodologia utilizada nesta produção foi a de observação participante, viabilizada pelas interações online.

A estruturação do presente artigo foi pensada da seguinte forma: na primeira seção apresentamos a escola e sua proposta, e refletimos sobre como o corpo docente e a coordenação procuraram reinventar suas práticas durante esse período tão desafiador. Na segunda seção, relatamos experiências vividas com uma turma de crianças de 3 a 6 anos, demonstrando como é possível ouvir suas vozes, validar seus saberes e construir uma proposta que tenha significado e que estimule a movimentação corporal, a criação e a imaginação, mesmo em frente às telas. Já na última seção, refletimos sobre como fomos afetadas por esse inesperado momento, e de 


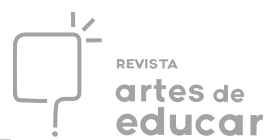

que maneira foi possível, junto com a comunidade escolar, resistir perante as dificuldades apresentadas pelo novo cenário. Dessa forma, alinhamos nossas considerações finais, concluindo que os encontros virtuais com crianças pequenas estão longe de ser o ideal, mas foi através deles que conseguimos propor atividades que valorizassem o imaginário criativo e o brincar como ferramentas de mediação da aprendizagem.

\section{Proposta pedagógica e outros caminhos: uma aposta na relação com as crianças}

A escola à qual nos referimos pertence à rede privada de educação e está localizada na cidade do Rio de Janeiro, mais especificamente no bairro das Laranjeiras. Sua proposta pedagógica sempre se pautou nos documentos que norteiam as práticas com crianças de 1 a 5 anos de idade: as Diretrizes Curriculares Nacionais para a Educação Infantil (BRASIL, 2010) e a Base Nacional Comum Curricular (BRASIL, 2017). Esses documentos afirmam que as atividades não presenciais não devem ser assumidas na educação de crianças, desde bebês, porque não possibilitam que as brincadeiras e interações norteiem os projetos pedagógicos. Além desses documentos, podemos citar também a Lei de Diretrizes e Bases da Educação Nacional (BRASIL, 1996), que não prevê o uso de atividades e práticas similares à Educação à Distância na Educação Infantil. Essa foi a maior dificuldade encontrada não só pela nossa escola, mas por tantas outras, em tempos de afastamento social: como manter vínculos afetivos e proximidade com nossas crianças com as escolas fechadas?

Cabe ressaltar que entendemos o vínculo afetivo como um processo de escuta, atenção, partilha, apoio e envolvimento entre o educador e o educando, estabelecendo entre ambos uma relação de confiança. Compreendemos que o vínculo afetivo também representa um cuidado, na medida em que "propicia a reinvenção da educação, fortalecendo o sentido de acompanhar o outro ampliando suas experiências de mundo. Permite que as crianças e suas expressões ganhem destaque" (GUIMARÃES, 2008, p. 54).

A escola, principalmente de Educação Infantil, precisa buscar construir a cada dia a valorização e a expressão de crianças e adultos. Precisamos de infâncias, brincadeiras, troca, contato físico e vínculo afetivo para formar sujeitos críticos, confiantes, autônomos, cooperativos e criativos. "É importante percebê-las e afetá-las", criando "um novo modo de escutar, ver e relacionar-se com as crianças, num caminho humanitário e ético" (GUIMARÃES, 2008, p. 43). 
O trabalho, na nossa escola, tem a pretensão de enriquecer cada vez mais as experiências cotidianas e, por isso, organizamos os grupos de forma não seriada, o que garante a convivência entre crianças de diferentes idades. As turmas foram organizadas por agrupadas 1 (crianças de 1 a 3 anos) e agrupadas 2 (crianças de 3 a 6 anos). Pensamos que esses encontros, com as diferentes idades, podem favorecer a interação e a troca, ampliando o desenvolvimento social, emocional e cognitivo de todas as crianças. Com isso, observamos, em nossas vivências, que as crianças das agrupadas aprendem a respeitar as individualidades - desenvolvendo o cuidado de si e do outro -, as diferentes possibilidades de troca, a paciência e a responsabilidade, tornando o cotidiano potente e plural.

Todos temos muito o que aprender no encontro com o outro, independentemente de idade, cultura e condições sociais. Segundo Paulo Freire: "quem ensina aprende ao ensinar e quem aprende ensina ao aprender" (FREIRE, 1996, p. 23). Da mesma forma acontece entre as próprias crianças. A criança mais nova experimenta grandes aprendizados ao estar ao lado de crianças mais velhas, mas os "pequenos" também trazem muitos desafios, provocando os de maior idade a repensarem, levantarem hipóteses e ampliarem cada vez mais o repertório de saberes, de maneira que aprendam a lidar com situações adversas e agucem as curiosidades pelo mundo ao redor.

Segundo Lev Vygotsky (1984), é por meio do convívio com o outro que nós, seres humanos, nos constituímos. O autor elaborou o conceito de Zona de Desenvolvimento Proximal (ZDP), no qual entende que as crianças ampliam seu potencial de aprendizagem quando estão acompanhadas de outros sujeitos capazes de desenvolver problemas mais complexos do que elas. Dessa forma, a criança que, sozinha, consegue solucionar determinado desafio, alcançará outro problema quando em parceria com pares mais experientes naquele quesito. A partir dessas trocas enriquecedoras, vão ampliando seus próprios recursos, tornando mais complexas as estratégias para solucionar questões sociais, emocionais e cognitivas.

Para propiciar a busca de respostas às perguntas que as crianças trazem e que em nossa proposta pedagógica ganham evidência, o currículo da escola se efetiva por meio de projetos. Os temas são escolhidos pelas turmas. Nos grupos com crianças de 1 a 3 anos, o interesse é observado pelo educador, por meio dos gestos individuais e coletivos, a curiosidade por objetos, brincadeiras, músicas ou por histórias, por exemplo.

As crianças são antífonas pequenas que respondem ao canto do chão quase num boca a boca. Aqui, a mão obreira se mescla com o olho contemplativo até que seus inversos se complementam no verso poético: o olho faz e a mão contempla. Ambos num corpo brincante apaixonado e apaixonante que, se o 
destino for benevolente, nos deixará o privilégio de ser húmus de novo e esterco às próprias custas! (PIORSKI, 2016, p. 17)

O educador tem papel imprescindível nessa escuta - que é a escuta de corpo inteiro, ou seja, passando pelo que verbaliza, pela sensorialidade, pelas expressões e pelos movimentos e é a partir desse olhar sensível que é possível escolher a temática do projeto. Cabe a esse profissional mediar, observar e provocar o desejo investigativo. Já nos grupos com crianças de 3 a 6 anos de idade, devido à maior desenvoltura na expressão de seus desejos - seja na verbalização ou através de gestos, olhares e movimentos -, os temas são escolhidos pelas próprias crianças, num processo democrático de consenso ou votação, mediada pelos educadores. Tanto na agrupada 1 quanto na agrupada 2, os objetivos são trabalhados de forma interligada e transversal.

Nesse processo pedagógico, a construção dos saberes das crianças é associada às práticas vividas, com sentido e significado, em busca de respostas para determinada provocação ou inquietação, adquirindo novos aprendizados, nas diferentes áreas, e ampliando suas ideias e opiniões sobre determinado assunto, de maneira a provocar uma reflexão de mundo. Essas experiências acontecem em nosso cotidiano, possibilitando, através do levantamento de hipóteses, investigações e trocas com parceiros, a oportunidade de decidirem, opinarem e debaterem juntos, construindo coletivamente conhecimentos. Assim, as crianças se tornam protagonistas do processo pedagógico, junto com os educadores.

Compete a nós, educadores, exercemos o papel de preparar um espaço provocador e proporcionar diferentes possibilidades de reflexões. O objetivo central é o de instigar as crianças a sentirem desejo pela procura de novas perguntas, traçando seu processo de investigação, no qual são valorizadas as suas culturas, histórias e forma de construir as próprias aprendizagens. Com essa concepção de respeito às individualidades, o mais importante é a valorização do processo, e não o produto final.

Diante da proposta pedagógica apresentada, na qual se evidencia que o currículo da Educação Infantil não está no papel e que o conhecimento para essa etapa não cabe em apostilas, vídeos "educativos" ou conteúdos descontextualizados diante de uma plataforma online, ficamos angustiadas com o cenário que se apresentava, de isolamento e fechamento das escolas bem no início do ano.

Inicialmente, as propostas em um cenário online não pareciam adequadas para a manutenção do vínculo afetivo nessa faixa etária, porque não asseguravam o papel ativo das crianças nas vivências proporcionadas. A escuta do corpo do outro ficou comprometida nesse 


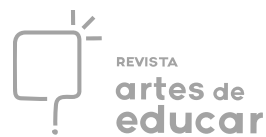

processo, pois começamos a nos relacionar com corpos cortados (só uma parte do corpo presente nas telas), omissos (câmeras fechadas), interrompidos (problemas constantes de conexão que congelavam imagens ou interrompiam a participação de alguém) ou emudecidos (os microfones fechados). Diante do novo contexto em relação com a nossa proposta pedagógica e curricular, surgiram diversas indagações: o que propor durante o afastamento social? Como manter o vínculo afetivo na Educação Infantil, abruptamente interrompido pela pandemia?

Além das questões apresentadas, também foi preciso reconhecer a importância da tecnologia como ferramenta essencial durante esse período, considerando também que seu uso exagerado não é indicado para crianças tão pequenas. Sabemos que a Sociedade Brasileira de Pediatria (SBP) recomenda um tempo adequado para cada faixa etária.

[...] a recomendação de exposição às mídias para crianças menores de dois anos é tempo zero, pois as evidências das pesquisas mostram que as interações sociais são muito mais eficazes e estimulantes para o desenvolvimento da linguagem, da inteligência, da interação social e das habilidades motoras, além de proporcionar momentos de aprendizagem global, capacidade de resolução de problemas e habilidades de controle emocional, tornando a criança um adulto mais saudável e resiliente. (SBP, 2019, p. 3)

Nesse sentido, precisamos nos reinventar, pensar juntos - educadores, familiares, coordenação e gestores - sobre os novos caminhos a serem trilhados nesse ano tão atípico, procurando também respeitar as bases do Projeto Político-Pedagógico da escola construído por toda a comunidade escolar. Dessa forma, as tecnologias digitais foram os recursos possíveis de serem utilizados, mas foi preciso aproveitá-las de forma muito cuidadosa e responsável.

\section{"É preciso ter esperança, mas do verbo esperançar (...)": nossas experiências durante o ano de 2020 e o enfrentamento da pandemia de covid-19}

Em abril de 2020, a escola fez cinco anos de existência. Durante esse período, toda a equipe de educadores, juntamente com a comunidade escolar, procurou investir em uma proposta que valorizasse as vozes das crianças em suas subjetividades. O processo de formação continuada de toda a equipe foi elaborado com base em um eixo principal para que pudéssemos mergulhar no universo infantil, investindo sempre no olhar e na escuta sensíveis e nos corpos brincantes. 
Conhecer a infância e as crianças favorece que o humano continue sendo sujeito crítico da história que ele produz (e que o produz). Sendo humano, esse processo é marcado por contradições: podemos aprender com as crianças a crítica, a brincadeira, a virar as coisas do mundo pelo avesso. Ao mesmo tempo, precisamos considerar o contexto, as condições concretas em que as crianças estão inseridas e onde se dão suas práticas e interações. Precisamos considerar os valores e princípios éticos que queremos transmitir na ação educativa. (KRAMER, 2007, p. 17)

Em nossos processos diários de formação, durante nossa recente história, procuramos aprender com nossas crianças, na tentativa de desconstruir nossas contradições e a aprender através da brincadeira, do olhar curioso e investigativo.

No início do ano letivo, em fevereiro, antes de começar o período de quarentena em função da pandemia de covid-19, iniciamos a formação continuada de todos os educadores (do porteiro à direção), com momentos de estudo, reflexão e ideias de novas experiências que poderiam ser vividas ao longo do ano. Nesse momento, pensávamos nos espaços, nos materiais, nos livros e nas vertentes que poderiam ser estudadas, através da escuta oral e corporal de cada criança e grupo, considerando o que mencionava Freinet (1932): "educar não é uma fórmula de escola, mas uma obra de vida" (apud SAMPAIO, 1994, p.117).

Movidos por esses sentimentos da vida, no dia 7 de março inauguramos o nosso baile carnavalesco, o Bloco do Travesseiro, nome este escolhido pelas crianças e votado por toda a comunidade escolar no final de 2018. Vivemos e experimentamos, mais uma vez, uma escola ativa, dinâmica e aberta para uma construção coletiva com todas as famílias. "A vida transcorre no cotidiano da escola, é aí que ela se afirma como potência ou impotência, de corpo e de espírito. Assim, a auto constituição e aprendizagem não são processos separados” (TIRIBA, 2006, p. 3).

Mas foi também em março que, após a publicação de decretos do Governo do Estado e da Prefeitura, a cidade do Rio de Janeiro passou a praticar o afastamento social, visando a diminuição do risco de contágio de covid-19 entre a população. Com isso, as escolas foram fechadas e muitas angústias e inseguranças foram experimentadas não só pelo corpo docente, mas por toda a comunidade escolar e pela sociedade.

Com o prolongamento do fechamento da escola, fomos assolados pela incerteza de como poderíamos seguir, mantendo os vínculos afetivos e a proximidade com crianças tão pequenas. $\mathrm{O}$ afastamento social nos colocou diante de uma situação inusitada, nunca vivida por nenhum de nós. Em função disso, além de adotarmos algumas medidas de aproximação com a 
comunidade escolar, continuamos refletindo intensamente sobre nosso posicionamento enquanto instituição privada de ensino diante do cenário pandêmico. O distanciamento se prolongou, certamente, para muito além do que esperávamos. Foi preciso, então, exercitar, a todo o momento, o cuidado individual, como forma de legitimar sentimentos, além de dialogar a respeito das bases nas quais estamos alicerçados enquanto escola.

Fazer uma pausa de nossas atividades foi necessário para que pudéssemos acolher tudo o que estávamos sentindo e vivenciando individual e coletivamente. Muitas reuniões virtuais foram realizadas com a equipe para que pudéssemos falar e elaborar tudo o que enfrentávamos. Nesse processo também fizemos um resgate dos nossos princípios e valores no trabalho com as crianças, compreendendo que a educação de qualidade precisa garantir que todos e todas aprendam e ensinem, desenvolvendo-se no que diz respeito aos aspectos emocional, cultural e social, para além do cognitivo.

Ao longo de nossos encontros virtuais surgiu um lindo movimento, vindo, principalmente, dos professores, sobre a necessidade de resgatar as nossas esperanças. Esperança no futuro, esperança nas crianças e também em nossas potencialidades. Cortella, ao refletir sobre os ensinamentos de Paulo Freire, nos presenteia com lindo apontamento sobre a necessidade de se “[...] ter esperança, mas do verbo esperançar” (CORTELLA, 2015, p. 22). E esse foi um momento que, sem dúvida, nos desafiou fortemente, exigindo de todos a força da esperança, inerente ao ser humano. O conceito "esperançar" nos trouxe a ideia de movimento, de ação. Fomos inundados pelo sentimento de intervenção no mundo de forma coletiva, com o outro.

A partir desse momento, começamos a pensar em propostas para nossas crianças e famílias, priorizando o respeito às infâncias. E foi por acreditarmos em uma Educação Infantil pautada nas interações e em práticas educativas intencionalmente voltadas para as experiências cotidianas, que nos dispusemos, nos primeiros meses, a gravar vídeos ou áudios e escrever bilhetes - ora para as turmas, ora para cada criança - na tentativa de, enquanto escola, nos mantermos próximos de nossa comunidade. Nesses vídeos, procuramos compartilhar vivências, mostrar atividades cotidianas, bem como provocar as crianças a interagirem conosco e a contarem as novas experiências vividas em suas casas.

Além disso, por reconhecer que a escola possui uma função social de formação não só de seus educandos e educandas, mas de toda a comunidade, utilizamos nossos canais digitais como fonte de propagação de informação ao publicar notícias não só sobre a pandemia, mas também artigos e atividades lúdicas que pudessem amparar os responsáveis nesse período tão angustiante. Em nossas mídias, também publicamos vídeos de atividades cotidianas, contação Revista Interinstitucional Artes de Educar. Rio de Janeiro, V. 7, N. 1 - pág. 522-548 janeiroabril de 2021: "Pedagogias Vitais: Corpo, Desejo e Educação" DOI: 10.12957/riae.2021.55378 
de histórias e ideias de atividades baseadas em nossas práticas presenciais. Essas medidas tiveram como objetivo ampliar o repertório das famílias e, também, servir como rede de apoio a todas e todos os interessados no assunto.

É bem verdade que o trabalho em ambiente virtual gerou muitas inseguranças, ansiedades, sobrecargas físicas e emocionais e até mesmo tristeza, evidenciando um sentimento de impotência diante de nossas práticas. Ainda estamos tendo que nos reinventar a cada dia, tanto como profissionais da área de Educação, quanto como indivíduos em meio à nova realidade. Por isso, realizamos o exercício coletivo de, primeiramente, olhar por uma outra perspectiva, de forma que pudéssemos descobrir diferentes possibilidades e caminhos.

No início de julho, tentando atender as demandas da comunidade escolar, lançamo-nos frente a um novo desafio: construir uma proposta virtual para crianças tão pequenas, de 1 a 6 anos. Nossa dúvida era como construí-la, respeitando o tempo das crianças e famílias e tendo como norte os direitos de aprendizagem propostos por vários documentos que norteiam nossa prática, de forma a respeitar os documentos legais que não recomendam ou não preveem atividades não presenciais na educação de bebês e crianças.

Muitos questionamentos foram levantados pela equipe pedagógica durante esse período: como pensar em uma prática contextualizada? Como respeitar as angústias e tristezas vividas em cada lar? Como não se exceder no uso de telas e mídias? Como saber os interesses de cada criança, respeitando suas individualidades? Como dar continuidade a uma proposta investigativa e que utilize as múltiplas linguagens? Como ensinar e aprender sem estar junto? Como mediar nossos encontros sabendo que os responsáveis não têm formação pedagógica? Como não exigir demais, mas também como não se distanciar?

A escola que buscamos construir a cada dia valoriza a expressão com o corpo inteiro, com todos os sentidos, tanto das crianças como dos adultos. As subjetividades são a nossa principal ferramenta de trabalho, uma vez que também validamos nossos sentimentos - crianças e adultos - cotidianamente, mostrando aos pequenos que é possível sentir alegria e chateação, por exemplo, e acolhê-los de forma respeitosa, ajudando-os a encontrar novas possibilidades para resolver seus conflitos.

Nosso principal objetivo é formar sujeitos éticos, capazes de ter empatia pelo outro e espírito de coletividade, tão necessários para uma convivência respeitosa em sociedade. Como fazer, então? Houve muitas dúvidas justamente por estarmos preocupados com a formação de sujeitos pertencentes e criadores do mundo, representando, como aponta Paulo Freire, uma “luta para não ser apenas objeto, mas sujeito também da história” (FREIRE, 1996, p. 54). 
Também se faz necessário reconhecer que a tecnologia pode ser uma ferramenta potente e, nesses últimos meses, se apresentou como essencial, considerando o afastamento social. Porém, também há de se ponderar a orientação da Sociedade Brasileira de Pediatria (SBP, 2019) sobre o tempo adequado para o uso de tela, tendo em conta cada faixa etária. Pensando nisso, nos propomos a fazer, primeiramente, um encontro virtual por semana com a duração máxima de uma hora para as turmas com crianças de 3 a 6 anos. Nesses encontros, procuramos planejar atividades que despertassem o corpo brincante e estimulassem a curiosidade, além de priorizar um espaço de escuta e acolhimento, pelo qual seria possível ouvir e perceber os desejos investigativos das crianças.

Para que a proposta das rodas virtuais se tornasse possível, foi necessário convocar a participação das famílias. Os responsáveis ficaram incumbidos de preparar o ambiente, auxiliar a criança durante a atividadee e separar os materiais solicitados. Cada família recebia um bilhete alguns dias antes, que relatava brevemente como aconteceria o próximo encontro e listava os materias necessários para que a proposta fosse realizada. Também cabia a cada família avaliar suas condições e decidir sobre a viabilidade de participar desses encontros.

\section{“O Apanhador de Desperdícios": Relato de experiência com uma turma de crianças de 3}

\section{a 6 anos em tempos de pandemia}

Uso a palavra para compor meus silêncios.

Não gosto das palavras fatigadas de informar.

Dou mais respeito às que vivem de barriga no chão tipo água pedra sapo.

Entendo bem o sotaque das águas Dou respeito às coisas desimportantes e aos seres desimportantes. Prezo insetos mais que aviões.

Prezo a velocidade das tartarugas mais que a dos mísseis. Tenho em mim um atraso de nascença.

Eu fui aparelhado para gostar de passarinhos. Tenho abundância de ser feliz por isso. Meu quintal é maior do que o mundo. Sou um apanhador de desperdícios:

Amo os restos como as boas moscas.

Queria que a minha voz tivesse um formato de canto. 


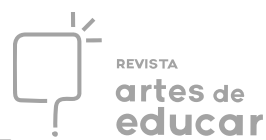

Porque eu não sou da informática: eu sou da invencionática Só uso a palavra para compor meus silêncios.

Manoel de Barros

Partindo da leitura desse belíssimo poema de Manoel de Barros (2010, p. 13), começamos a perceber nossas experiências com a nova realidade virtual de forma "invencionática", em vez de informática. Evidenciando o olhar infantil de "apanhador de desperdícios", pautado na poética da simplicidade, fomos nos formando para atuar dentro da plataforma virtual de maneira que fosse possível manter nossos sentidos atentos aos gestos, palavras e movimentações de nossas crianças. A capacidade de imaginação, criação e (re)invenção continuou sendo nosso norte nessa nova caminhada, junto com as leis já mencionadas.

$\mathrm{Na}$ escola, quando recebemos um novo grupo, vamos, aos poucos, nos conhecendo pelas observações corporais e orais, pela construção de vínculos com os pares e adultos, espaços, objetos, brincadeiras e rodas de conversas coletivas e individuais. Ao longo de alguns meses, diante dessas observações, vamos nos constituindo enquanto coletivo, ficando evidente a necessidade de registrarmos nossa identidade, por meio de um nome. É nas rodas de conversas que decidimos, coletivamente, o nome da turma. E, não simultaneamente, traçamos, através do olhar do educador e da percepção do desejo das crianças, uma ideia de projeto a ser desenvolvido, fortalecendo a vinculação entre os membros dos grupos. Primeiro é feito um levantamento de todas as possibilidades e escolhas. Quando todas as opções são registradas no quadro, o grupo decide de forma democrática o nome da turma.

Foi em março de 2020 que, após esse processo, constituímos a turma do Raio, composta por 15 crianças de faixa etária entre 3 e 6 anos de idade. É sobre esta turma que apresentaremos agora o relato das experiências virtuais vividas durante os meses de afastamento social.

A turma do Raio esteve reunida presencialmente por apenas algumas semanas antes do fechamento da escola. O grupo ainda estava decidindo o que iria estudar e investigar. Começávamos a provocar indagações quando nossos levantamentos e debates foram interrompidos. De repente, nos vimos obrigados a ficar em nossas casas, como forma de cuidado e proteção, conversando apenas por telefone, mensagens, fotos e vídeos.

Não foi fácil pensar em uma Educação Infantil adaptada ao mundo virtual, por isso, quando nos fortalecemos enquanto coletivo, procuramos definir alguns nortes principais para nossa nova realidade. Com isso, elegemos a escuta, o diálogo e a formação de crianças ativas, brincantes e investigativas como nossos eixos principais, mesmo no mundo virtual. Visamos oferecer a possibilidade para que nossas crianças caminhassem no seu tempo, valorizando o seu Revista Interinstitucional Artes de Educar. Rio de Janeiro, V. 7, N. 1 - pág. 522-548 janeiroabril de 2021: "Pedagogias Vitais: Corpo, Desejo e Educação" DOI: 10.12957/riae.2021.55378 
processo e compreendendo que o erro faz parte da construção do aprendizado, pois as crianças exploram através dos sentidos, por levantamento de hipóteses, com trocas entre pares e com os adultos. É preciso aguçar o desejo de buscar soluções da vida e que elas não desistam de "tatear, de investigar, para tentar resolver a imensidade de problemas dos quais depende seu destino" (FREINET, 1998, p. 101).

Cabe também reconhecer os limites desse processo. Por mais que planejássemos atividades, brincadeiras e novas explorações, tínhamos a consciência de que estávamos diante de um novo modelo de trabalho. Cada um, dentro de sua casa, sabia de seus limites e possibilidades e, individualmente, poderia eleger suas prioridades. Nós, enquanto escola, nos colocamos disponíveis para ser um espaço de acolhimento, escuta e diálogo, na constante tentativa de compreender as limitações (nossas e dos outros).

A partir disso, estruturamos encontros chamados de "rodas virtuais", com o intuito de acolher as experiências vividas por essas crianças, durante o período de afastamento do espaço escolar. Nem todas as famílias aceitaram esse formato virtual ou tiveram a possibilidade de participar, compreensivelmente, elegendo suas prioridades nesse difícil momento de trabalho excessivo de home office. Nas primeiras rodas, eram muitas as narrativas, e estas acabavam se embolando durante nossos encontros virtuais. As crianças que estiveram presentes estavam eufóricas para falar, felizes ao se verem e tudo representava grande novidade e festa pelo simples fato de estarem juntas, mesmo que diante de uma tela. Aos poucos, fomos conversando e estabelecendo combinados, como fazíamos na escola, dando oportunidade para que cada um pudesse falar e ser ouvido, respeitando o direito de vez e voz de todos.

A escuta de seus processos investigativos e de como estavam se sentindo foi o momento mais importante de nossas primeiras rodas. Gradativamente, nós, educadoras, fomos percebendo quais foram suas experiências vividas em casa e quais eram os atuais interesses investigativos de cada criança ou de pequenos grupos. Nesse sentido, buscamos respeitar o mundo natural de cada criança, valorizando suas experiências cotidianas, pois "quando a criança percebe que a escola continua a vida, vem para a aula com os olhos vivos, a boca confiante, as mãos cheias de riquezas que a fizeram parar pelo caminho" (ELIAS, 1997, p. 63).

Em um dos encontros virtuais, uma criança nos surpreendeu com a seguinte frase: “investigo o mundo para saber como ele é" ( $\mathrm{A}^{\mathrm{iv}}, 5$ anos e 8 meses). Foi partindo dessa fala que começamos a busca pelos atuais desejos de cada um, dentro desse coletivo.

Como pontapé inicial, indicamos que as famílias assistissem a um episódio do desenho Sid o cientista - A lupa, disponível no YouTube. ${ }^{\vee}$ Logo depois, em um encontro virtual, Revista Interinstitucional Artes de Educar. Rio de Janeiro, V. 7, N. 1 - pág. 522-548 janeiroabril de 2021: "Pedagogias Vitais: Corpo, Desejo e Educação" DOI: 10.12957/riae.2021.55378 
lançamos a proposta de as famílias fazerem uma maleta ou caixa de investigação. Essa caixa (confeccionada com sucata) poderia ser desenhada ou pintada como desejassem e, dentro dela, poderiam escolher alguns objetos de investigação. Nos encontros, percebemos diferentes objetos nas caixas (Figura 1), tais como: lupas, livros, pedras, conchas, binóculos, brinquedos, dinossauros e outros materiais.

Figura 1 - Caixas de investigadores confeccionadas pelas crianças da turma do Raio.
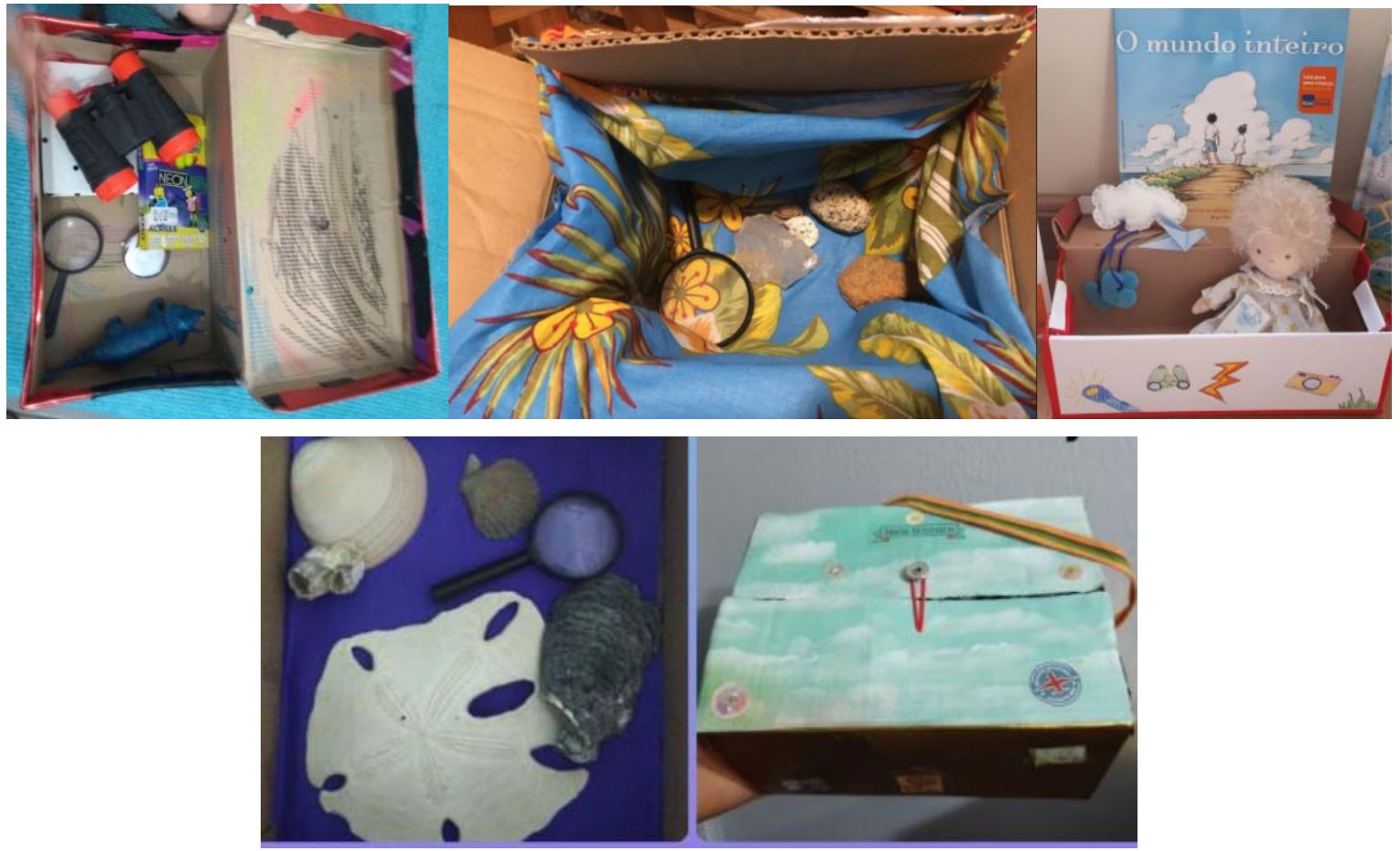

Fonte: Acervo de imagens da escola, 2020.

A partir dessas caixas, fomos ouvindo e observando os interesses das crianças que passavam pelos estudos dos dinossauros, carros de corrida, rochas, elementos da natureza, navegação e piratas. Em um outro dia de encontro, após a leitura do livro Nicolau tinha uma ideia (1998), de Ruth Rocha e Mariana Massarani, de repente uma das crianças disse que seria muito legal se pudéssemos "construir uma máquina do tempo para voltar para a época antes do coronavírus" (H., 5 anos e 1 mês). Uma das crianças prontamente concordou, dizendo que achava esse vírus "muito chato e idiota" (G., 4 anos e 8 meses). Com isso, aproveitamos para lançar para o grupo a proposta de construirmos nossas próprias máquinas do tempo. Usando a imaginação, poderíamos usá-la para viajar para épocas e lugares variados. Prontamente, a turma do Raio se mostrou muito animada. Educadoras, crianças e famílias embarcaram nessa aventura. 
O grupo passou uma semana construindo suas máquinas do tempo. Conversamos com as crianças e os responsáveis, no encontro anterior, sobre a importância de investigar, idealizar e desenhar a máquina, e pedimos que listassem os materiais necessários para a construção. Usando imaginação, criatividade e ludicidade, cada família escolheu o material para construir a máquina do tempo. Usaram muito luzes, tecidos, estruturas de papelão, pedras, conchas e outros materiais, de forma que a criatividade das crianças e de seus familiares fosse potencializada em todo o processo.

Quando chegou o dia da grande inauguração, percebemos a empolgação de crianças, famílias e educadoras! Brincamos, virtualmente, de fazer alguns ajustes (a máquina de uma das professoras havia quebrado, mas, de forma coletiva e com as ferramentas nas mãos dela, todos colaboraram com o conserto). Para dar início ao funcionamento da máquina, testamos algumas palavras mágicas e, de repente, tudo tremeu! Tremeu de verdade! Computadores, celulares e a própria máquina de algumas crianças (Figura 2) balançaram.

Figura 2 - Máquinas do tempo da turma do Raio.

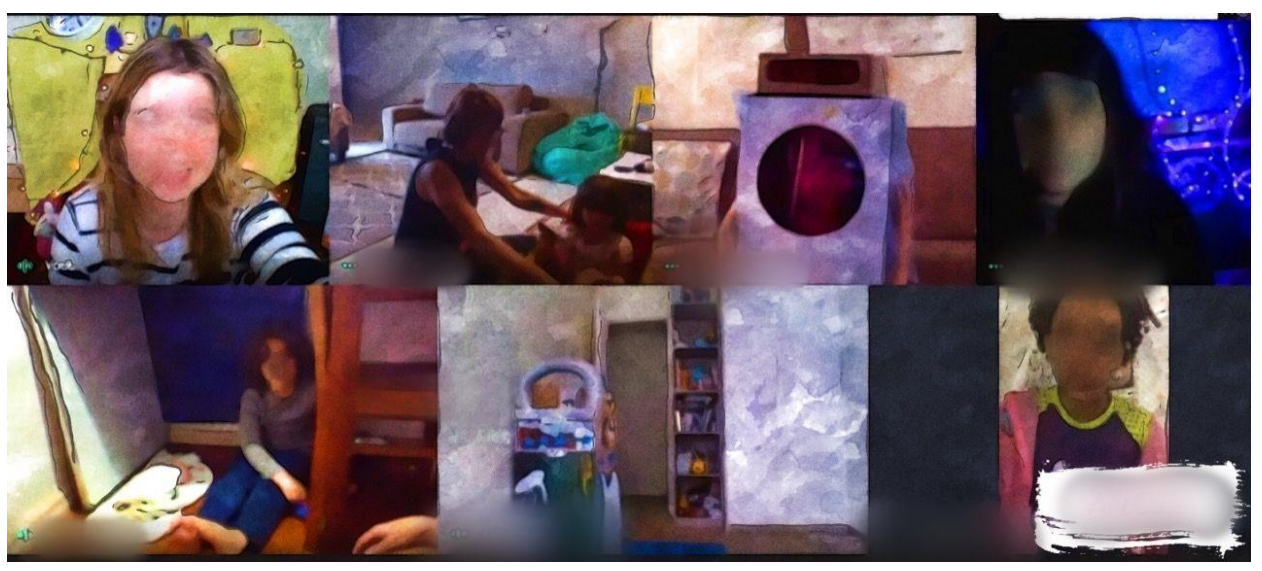

Fonte: Acervo de imagens da escola, 2020.

Nossa primeira viagem foi rumo ao ano de nascimento de cada integrante do grupo, trazendo suas histórias e sua identidade. Vimos fotos de todos quando bebês e descobrimos o que cada um estava fazendo nessa época, além de filmes que estavam em cartaz e eventos interessantes. Aproveitamos esse momento para estimular nossos corpos brincantes e fomos direto para o ano de nascimento de uma das crianças, 2015. Fizemos uma parada nesta época, mais especificamente no Canadá, para ver a equipe brasileira de ginástica rítmica ganhar a medalha de ouro na apresentação das fitas nos Jogos Pan-Americanos. Ao compartilhamos na tela o vídeo desse momento, o grupo se mostrou encantado. Com os olhos atentos a cada passo e movimento, ouviámos, em alguns momentos, a expressão "uau!". Depois da apresentação da equipe de ginástica artística, rítmica e acrobática, lançamos a proposta de dançarmos com fitas

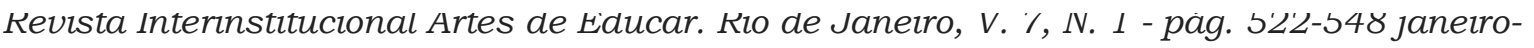
abril de 2021: "Pedagogias Vitais: Corpo, Desejo e Educação" DOI: 10.12957/riae.2021.55378 
ou algo similar ao som da mesma música do vídeo assitido pelo grupo. Cada criança realizou diferentes movimentos que foram observados atentamente por cada um: círculos, lançamentos e capturas, giros e outros, utilizando o corpo e o objeto, dando ideias para seus colegas. Foi lindo e emocionante!

Atendendo aos muitos pedidos de viajarmos para a época dos dinossauros, marcamos o encontro seguinte com o objetivo de fazermos uma trilha na selva! Pensamos em uma proposta que envolvia muita imaginação, os sentidos e também o corpo brincante. Começamos nossa viagem separando itens importantes para uma caminhada. Nesse momento, nos reunimos e listamos o que cada um tinha levado de importante para a aventura. Algumas crianças separaram água, biscoito e binóculos, outras, repelente e chapéu, e também houve quem levasse bússula e lanterna. Com muita animação, usamos nossa palavra mágica e tudo tremeu novamente! Familiares e educadoras sacudiram as telas de seus computadores e celulares. Crianças se balançaram em suas máquinas até que chegamos a um lugar com sons de dinossauros. Que medo! O que será que havia lá fora? Será que encontraríamos esse animal tão temeroso?

Imaginamos que estávamos no período Jurássico e "saímos" da máquina para explorar o local (Figura 3). Rastejamos pela mata e rolamos para nos esconder atrás de pedras (representadas por mesas e cadeiras). Andamos com um pé na frente e o outro atrás para atravessar uma ponte muito perigosa, corremos de uma Razana. ${ }^{v i}$ Subimos em uma árvore (representada pelo sofá) e usamos binóculos imaginários ou reais para avistarmos um Pterodáctilo vindo em nossa direção. Pulamos imediatamente e nos escondemos em cavernas (embaixo das cadeiras) para apreciarmos a vista de Braquiossauros comendo folhas de árvores.

Essa foi uma aventura que, com certeza, demandou muito imaginação, desejo e movimento, e nos aproximou da realidade! Tudo conduzido pela narração das professoras com um enredo tecido junto com as crianças, com o auxílio de sons, imagens, vídeos e corpos "vivos", diante das telas, experimentando cada um dos desafios propostos.

Figura 3 - Nossa trilha no período Jurássico.

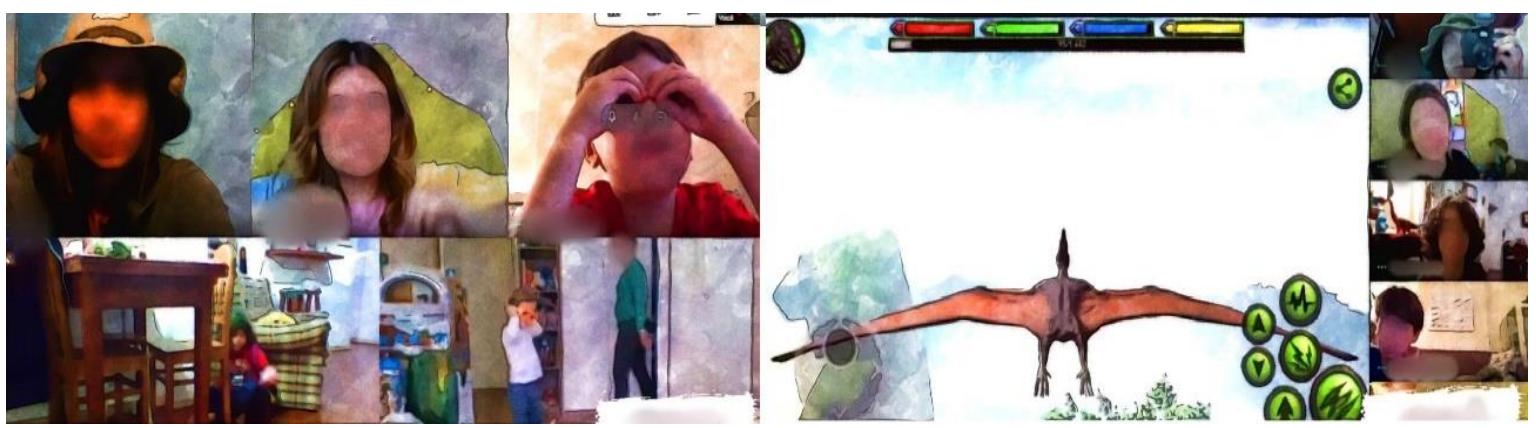

Revista Interinstitucional Artes de Educar. Rio de Janeiro, V. 7, N. 1 - pág. 522-548 janeiroabril de 2021: "Pedagogias Vitais: Corpo, Desejo e Educação" DOI: 10.12957/riae.2021.55378 
Fonte: Acervo de imagens da escola, 2020.

Ouvir o grupo dizendo que a aventura tinha sido "o máximo!" foi muito gratificante. Quanto prazer em viver esse dia brincante com crianças e famílias que, mesmo dentro de suas casas, conseguiram imaginar todo um cenário, como se estivéssemos juntos (em um mesmo ambiente, com trocas coletivas e corporais), trilhando de verdade aquela trilha. Nessas atividades podemos observar que:

A imaginação é para a criança um espaço de liberdade e de decolagem em direção ao possível, quer realizável ou não. A imaginação da criança move-se junto - comove-se - com o novo que ela vê por todo o lado no mundo. Sensível ao novo, a imaginação é também uma dimensão em que a criança vislumbra coisas novas, pressente ou esboça futuros possíveis. Ela tem necessidade da emoção imaginativa que vive por meio da brincadeira, das histórias que a cultura lhe oferece, do contato com a arte e com a natureza, e da mediação adulta: o dedo que aponta, a voz que conta ou escuta, o cotidiano que aceita. (GIRARDELLO, 2011, p. 76)

Nos encontros seguintes, fizemos desdobramentos dessa experiência e as crianças tiveram que pesquisar mais sobre os dinossauros da época Jurássica para contar ao menos uma curiosidade aos amigos. Construímos rabos de dinossauros (com revista, jornal ou fronha, e barbante) e dançamos ao som da música "Jacaré Poiô", do Cacuriá de Dona Teté, dança típica do Estado do Maranhão. Foi, inclusive, no Maranhão que descobrimos a existência de um dinossauro com um nome bem parecido com o da turma, o Rayosossauro. Com ajuda do livro Dinos do Brasil (2018), de Luiz Anelli, descobrimos algumas curiosidades sobre esse animal.

Depois aproveitamos a oportunidade para usar mais uma vez nossa imaginação e as máquinas do tempo e "viajamos" até a Ilha do Cajual para brincarmos de paleontólogos em busca de um fóssil desse novo animal que era desconhecido por todos nós. Na brincadeira, separamos utensílios de paleontólogos, tais como martelos e picaretas de brinquedos, além de pincéis. Pedimos para que os adultos responsáveis separassem uma bacia e, no fundo, colocassem o desenho de um pedaço do esqueleto de dinossauro e que cobrissem com areia ou similar (Figura 4). A brincadeira pareceu bem divertida!

Figura 4 - Brincando de paleontólogos. 


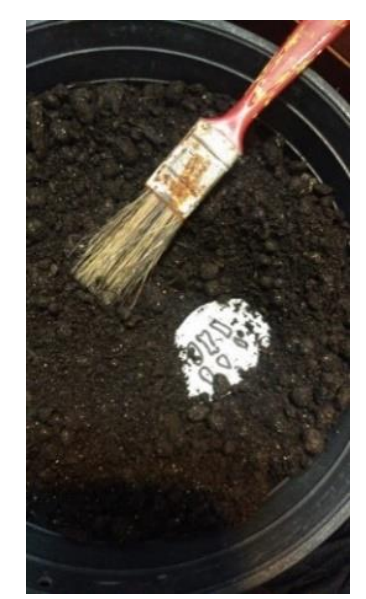

Fonte: Acervo de imagens da escola, 2020.

A partir dessa vivência, decidimos contar a história desse dinossauro em um livro escrito, narrado e desenhado por todo o grupo (Figura 5). Como os pesquisadores pouco descobriram sobre o Rayosossauro, resolvemos juntar tudo o que investigamos sobre ele e outros dinossauros para construir uma narrativa coletiva. Usamos a ferramenta de compartilhamento da tela para abrir nosso bloco de notas e escrevemos, juntos, uma "longa história" (F., 5 anos e 8 meses) inédita. Quando terminamos a revisão do texto, cada integrante do grupo (crianças, responsáveis e educadoras) teve a oportunidade de desenhar uma parte da história e gravar um aúdio. Com isso, conseguimos compilar em arquivo de imagem (livro) e também de vídeo (audiolivro) essa incrível história, que ainda será impressa e enviada para a casa de todas as crianças da turma como um presente especial.

Vale considerar que é na construção da escrita do texto coletivo que podemos:

[...] então observar a relevância do papel da linguagem. A construção coletiva de sentidos que vai se dando na troca discursiva. A importância da interação entre a fala do monitor e o pensamento das crianças, que vão sempre avançando em suas hipóteses. [...] Certamente as crianças não alcançariam a complexidade da reflexão que apresentaram se não fossem, ao mesmo tempo, desafiadas e amparadas pela fala do monitor. (MOURA, 2005, p. 6) 
Figura 5 - Alguns trechos do livro produzido pela Turma do Raio.

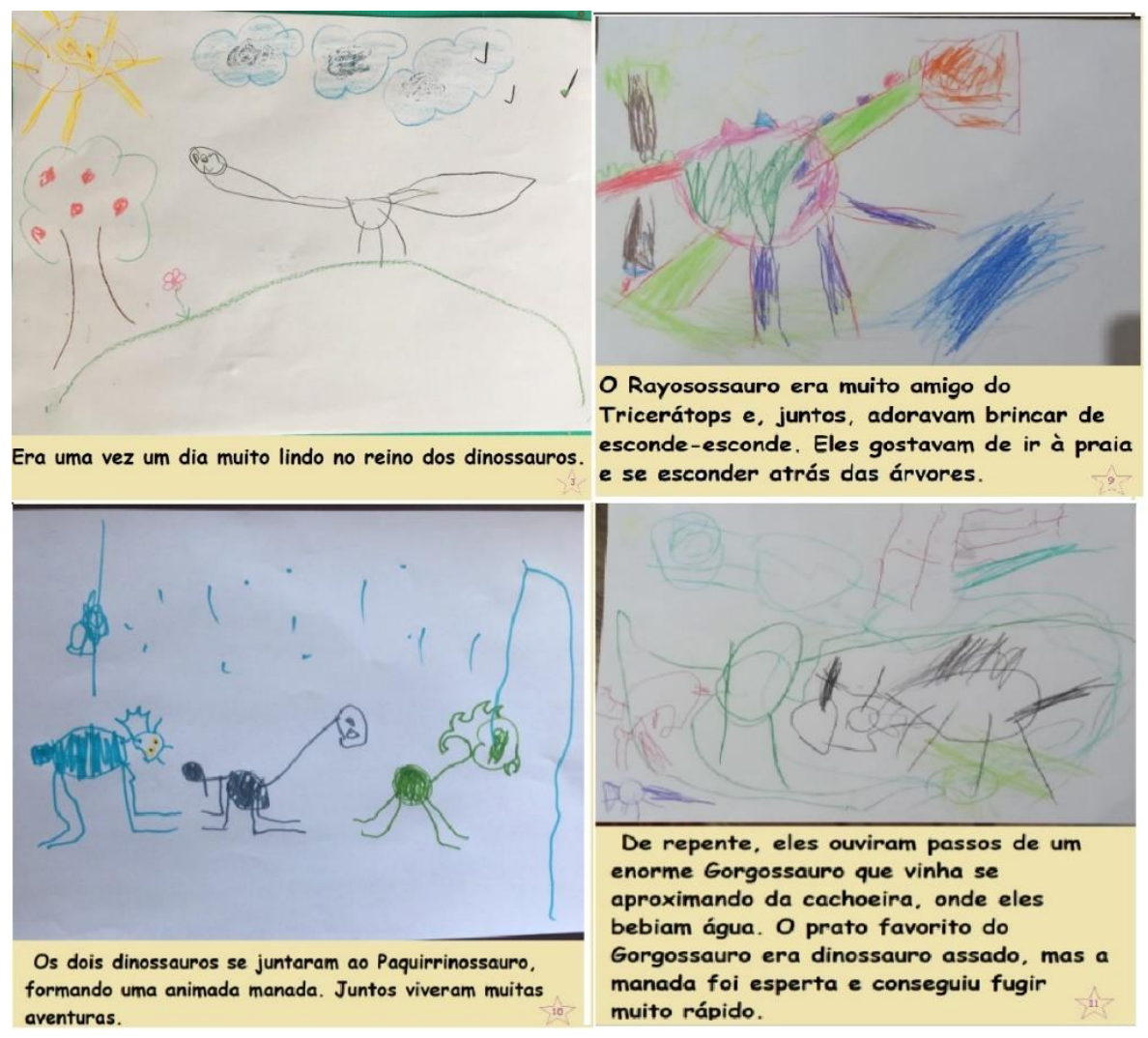

Fonte: Acervo de imagens da escola, 2020.

Nesse percurso, usamos mais uma vez os recursos tencnológicos ao nosso favor e fizemos a tão curtida aula-passeio. Escolhemos como destino o Museu Nacional de História Natural dos Estados Unidos, ${ }^{\text {vii }}$ pois a insituição disponibilizou em seu site a possibilidade de fazer um tour virtual em $360^{\circ}$. Esse encontro foi muito interessante, pois, além de fazermos nossas saídas de campo, também tivemos a oportunidade de "viajar" para outro país e conhecer um museu famoso no mundo todo por seu incrível acervo.

Vale destacar que as aulas-passeios são pensadas pela escola como um momento para vivenciar de perto o que está sendo estudado e, também, para despertar novos interesses e curiosidades, oportunizando o sentir com todo o ser, utilizando a sensibilidade natural (FREINET, 1973). Baseada em Freinet, Sampaio faz uma reflexão sobre esses momentos:

[...] a saída deve der encarada com muita responsabilidade, pois ao fazer os planos do passeio, preparar materiais necessários, estar atento ao roteiro da viagem, participar das tarefas durante a saída. o aluno, além de viver um aprendizado natural e agradável, tem a oportunidade de ampliar as formas de relacionamentos com colegas, professores e acompanhantes. [...] crianças decidem sairsimplesmente por prazer, pela curiosidade e interesse e não pela obrigação estabelecidas pelos objetivos educacionais da escola. (SAMPAIO, 1994, p. 181) 
Pensando nisso, a proposta de passear pelo museu - ainda que virtualmente - teve como objetivo, também, resgatar a memória afetiva desses momentos. Sendo assim, solicitamos que o grupo usasse a blusa da escola e levasse um lanche para compartilharmos durante a visita. Antes de sairmos para o passeio, uma das professoras fez alguns combinados, como de costume em todas as saídas que fazemos com as crianças:

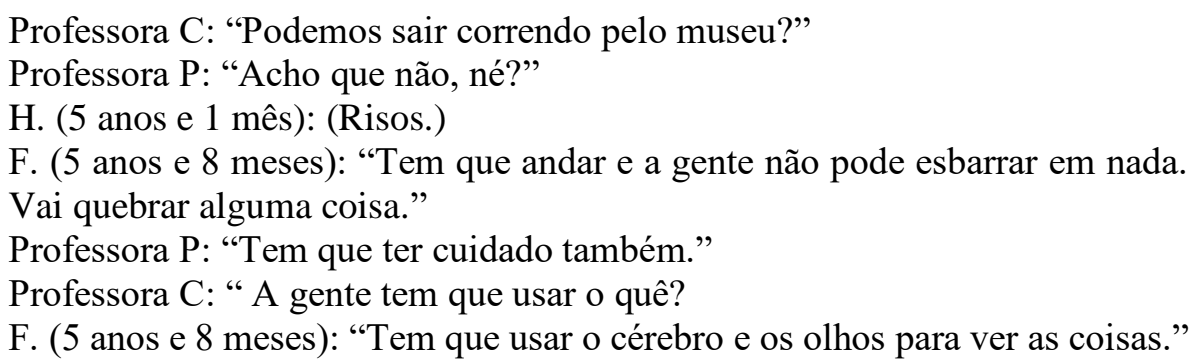

Quando o grupo foi questionado sobre como faria para chegar a outro país, sem rodeios as crianças levantaram suas hipóteses e decidiram que seria de avião! Brincamos de abrir as asas, afivelamos nossos cintos (uma criança pegou um cinto de verdade) e imitamos uma forte turbulência antes de aterrissarmos. Como nosso avião pousou bem pertinho do Museu, corremos para a entrada (Figura 6), a fim de observarmos diversos fósseis de dinossauros e descobrir ainda mais curiosidades sobre eles. Assim que entramos no saguão, as crianças gritavam: “Olha o mamute!”. Uma das crianças já foi logo dizendo: "Eu quero ir ao encontro dos dinossauros" (A., 5 anos e 7 meses). Durante a visita, a expressão mais ouvida foi: "Uau!".

Figura 6 - Visita virtual ao Museu Nacional de História Natural, EUA.

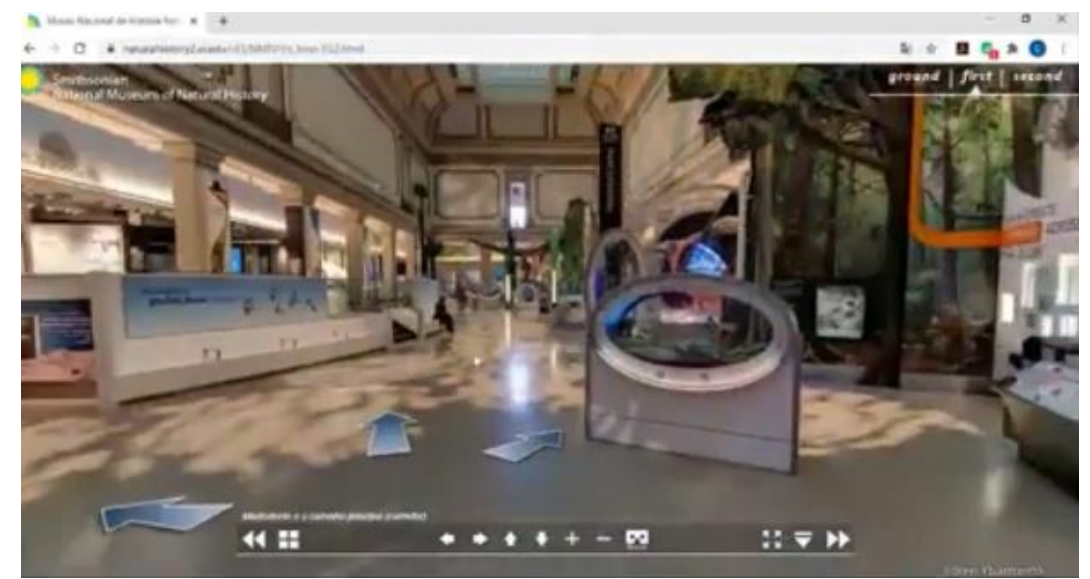

Fonte: Site do Museu de História Natural, Smithsonian. ${ }^{\text {viii }}$

“Caminhamos" pela exposição e descobrimos fósseis de mamíferos, plantas e dinossauros. Conseguimos observar, inclusive, o emblemático Tiranossauro Rex atacando o 


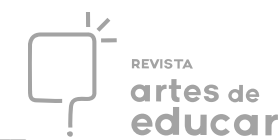

adorado Tricerátops, mas algumas crianças continuaram afirmando que o Tricerátops não estava sendo atacado, estava apenas "dormindo". Observamos atentamente como eram os dentes dos dinossauros carnívoros e dos herbívoros. Analisamos um Braquiossauro, com seu pescoço longo, e um Estegossauro, com suas placas e espinhos, e foi aí que entedemos como acontecia a dinâmica dos dinossauros defensivos e ofensivos.

Ah... o tão desejado piquenique também foi garantido! Depois de algum tempinho desbravando o museu, a A. (de 5 anos e 7 meses) já foi logo falando: "Estou faminta! Que tal se fizermos o nosso lanche agora? ”. Então, saímos à procura de um espaço para estender nossa toalha e ajeitar nossas comidas favoritas. Escolhemos um ponto estratégico do museu, bem em frente aos fósseis dos mais famosos dinossauros. Sentamos e ficamos conversando sobre o que vimos, além de comer pipocas, pães de queijo, maçãs e gelatinas (Figura 7). Aproveitamos também para conversar sobre a importância da preservação ambiental e sobre como nosso planeta tem mudado tão rápido, devido à influência predatória dos humanos. Que delícia dar uma paradinha para comer, conversar, trocar e descansar um pouquinho dessa visita tão incrível!

Figura 7 - Piquenique no museu.

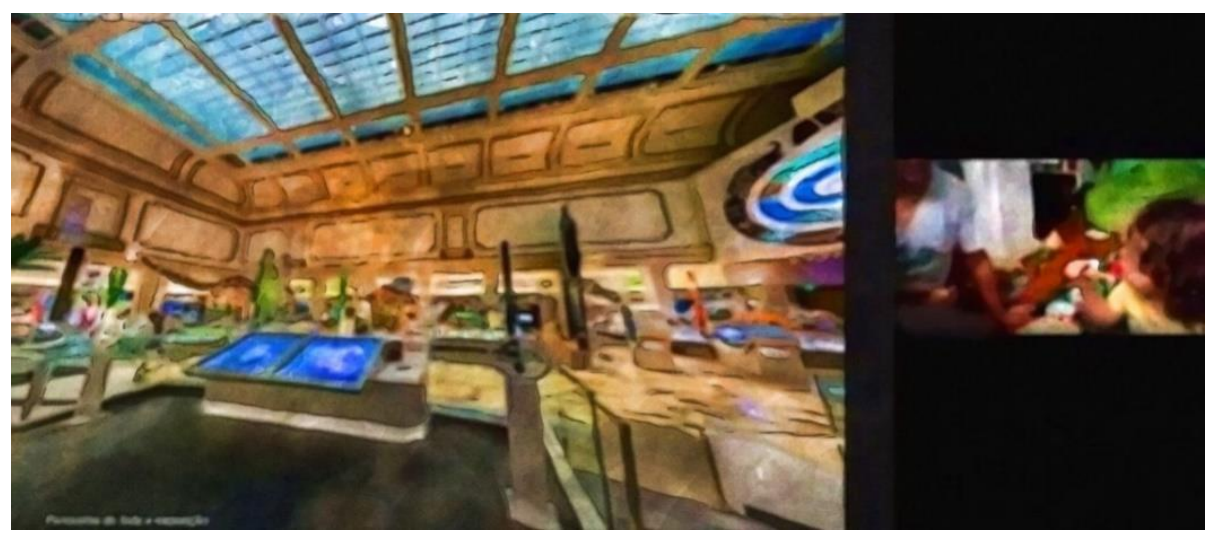

Fonte: Site do Museu de História Natural, Smithsonian, e acervo de imagens da escola, 2020.

Depois de tanta aventura, chegou a hora de nos despedirmos do Museu e voltarmos para nossos aviões. A viagem da volta foi ainda mais radical, pois uma das crianças deu a ideia de saltarmos de paraquedas enquanto comíamos pipoca! É até dificíl de imaginar essa proposta que, no mínimo, foi “radical!” (Figura 8). 
Figura 8 - Saltando de paraquedas e comendo pipoca.

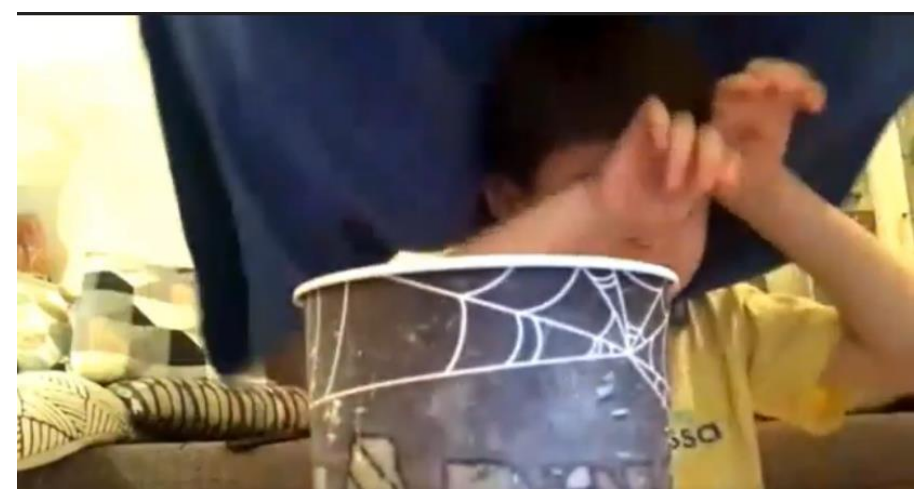

Fonte: Acervo de imagens da escola, 2020.

No fim, ao avaliarmos nosso passeio, ouvimos as crianças dizendo:

A. (5 anos e 7 meses): "Foi maneiríssimo!"

H. (5 anos e 1 mês): "Gostei."

F. (5 anos e 8 meses): "Eu gostei muito! Eu gostei mil estrelas!"

Esse passeio foi realmente delicioso e só foi possível fazê-lo porque estimulamos nossa imaginação e embarcamos todos numa mesma aventura. Todas as atividades que realizamos, principalmente nesse momento de afastamento social, têm tido como base fundamental as vivências imaginativas e criativas, aliadas a muita alegria e disposição. Para que seja possível manter corpos ativos frente às telas, com crianças participativas e investigativas, foi preciso investir ainda mais na ludicidade e na imaginação. Nesse sentido, vale apontar que:

As vivências imaginativas da infância têm um papel crucial no seu desenvolvimento estético, afetivo e cognitivo. Vimos que é possível atuar favoravelmente sobre a imaginação infantil, criando melhores condições para que as crianças disponham desse tempo ou lugar - metáforas para a imaginação - onde possam exercitar sua curiosidade sobre as coisas do mundo, constituir conhecimento sobre elas e sobre si próprias, e viver mais plenamente o imaginável [...]. (GIRARDELLO, 2011, p. 90)

Nossas aventuras virtuais ainda não terminaram e, com certeza, viveremos muitas outras histórias mediadas pela nossa incrível imaginação, utilizando as diferentes linguagens. A nossa máquina do tempo ainda será o fio condutor que interligará as diferentes temáticas eleitas pelo grupo. Que venham mais desafios e aventuras!

"No meio do caminho tinha uma pedra. Tinha uma pedra no meio do caminho": Considerações finais sobre a reinvenção de um trabalho que ainda não terminou

Revista Interinstitucional Artes de Educar. Rio de Janeiro, V. 7, N. 1 - pág. 522-548 janeiroabril de 2021: "Pedagogias Vitais: Corpo, Desejo e Educação" DOI: 10.12957/riae.2021.55378 
Diante de tudo o que vivemos nesse atípico ano de 2020, ficamos com a sensação de que pedras sempre existirão em nossos caminhos, como bem aponta Carlos Drummond de Andrade (1930) em sua poesia. E viver uma pandemia que nos obrigou ao afastamento social foi uma enorme pedra! No entanto, a esperança, a criatividade e o desejo de proporcionar experiências significativas na Educação Infantil pautadas na imaginação criativa, em corpos ativos e no incentivo à investigação nos fez perceber que era possível seguir em frente e se reinventar a cada momento. Tivemos sempre o compromisso com a escuta de cada criança e, através dessa observação, embarcamos no mundo imaginário, vivenciando novas experiências. Também não temos dúvida de que a parceira das famílias foi fundamental para que esse processo pudesse ser vivido!

É evidente que continuamos concordando que o uso de plataformas digitais e ferramentas virtuais não são ideais, ainda mais com crianças tão pequenas, e que essas ferramentas nem devem permanecer disponíveis após o fim do afastamento social. "Não há presente, tecnologia ou qualquer outro artefato que substitua a presença, o afeto e o vínculo de uma relação humana, especialmente quando falamos de desenvolvimento infantil" (HARTUNG, 2019, p. 2). Ainda assim, percebemos que, diante da necessidade, é possível (re)construir, junto com a comunidade escolar, caminhos possíveis, sem perder nossos vínculos afetivos, a alegria, a escuta, o desejo e o respeito às individualidades, dentro de um coletivo heterogêneo. Aos poucos, fomos (ainda estamos) "escovando" essa enorme pedra e encontrando novas formas de trabalho, respeitando sempre os nossos eixos centrais, que são o diálogo e a formação de crianças ativas, o ser brincante, as investigações, a interação com o outro e as múltiplas linguagens.

Tem sido interessante prestar atenção e refletir como esse processo de educação tem ganhado forma, diante das possibilidades e restrições na atualidade. Toda essa experiência tem sido desafiadora e, ao mesmo tempo, nutritiva para nós, educadoras, que, a cada dia, nos reinventamos na busca por novas maneiras de descobrir o mundo com as crianças. É difícil encontrar "novidades" quando mal estamos saindo de casa, pois muitas vezes parece que paramos no tempo, mas é aí que percebemos que temos muito dentro de nós. Não podemos descartar a nossa bagagem de histórias vividas, que deixam diferentes memórias afetivas marcadas em nossos corpos.

\section{REFERÊNCIAS}

Revista Interinstitucional Artes de Educar. Rio de Janeiro, V. 7, N. 1 - pág. 522-548 janeiroabril de 2021: "Pedagogias Vitais: Corpo, Desejo e Educação" DOI: 10.12957/riae.2021.55378 
ANDRADE, Carlos Drummond. Alguma Poesia. Ed. Pindorama, 1930.

ANELLI, Luiz E. Dinos do Brasil. Ilustrado por Felipe Alves Elias. 2. ed. São Paulo: Peirópolis, 2018.

BARROS, Manoel. Memórias Inventadas para crianças. Iluminuras de Martha Barros. São Paulo: Editora Planeta do Brasil, 2010.

BONDÍA, Jorge Larrosa. Notas sobre a experiência e o saber de experiência. Rev. Bras. Educ., Rio de Janeiro, n. 19, p. 20-28, 2002. Disponível em: <https://www.scielo.br/scielo.php?pid=s1413-

24782002000100003\&script=sci_abstract\&tlng=pt $>$. Acesso em 9 dez. 2020.

BRASIL. Lei de Diretrizes e Bases da Educação Nacional. Lei n. 9.394, 20 de dezembro de 1996. Disponível em: 〈http://www.planalto.gov.br/ccivil_03/leis/19394.htm> Acesso em: 04 out. 2020.

- Ministério da Educação. Secretaria de Educação Básica. Diretrizes curriculares nacionais para a educação infantil / Secretaria de Educação Básica. - Brasília: MEC, SEB, $2010 . \quad$ Disponível em: <http://portal.mec.gov.br/dmdocuments/diretrizescurriculares 2012.pdf $>$. Acesso em: 4 out. 2020.

Base Nacional Comum Curricular (BNCC). Educação é a Base. Brasília, MEC/CONSED/UNDIME, 2017. Disponível em: 〈http://basenacionalcomum.mec.gov.br/images/BNCC_EI_EF_110518_versaofinal_site.pdf> . Acesso em: 04 out. 2020.

CORTELLA, Mário Sérgio. Educação, convivência e ética: audácia e esperança. São Paulo: Editora Cortez, 2015

ELIAS, Marisa Del Cioppo. Célestin Freinet: uma pedagogia de atividades e cooperação. Petrópolis, RJ: Vozes, 1997.

FREINET, Célestin. As técnicas Freinet da Escola Moderna. Tradução: Silva Letra. Lisboa: Editorial Estampa, 1973.

Ensaio de Psicologia sensível. São Paulo: Martins Fontes, 1998.

FREIRE, Paulo. Pedagogia da autonomia: saberes necessários à prática educativa. São Paulo: Paz e Terra, 1996.

GANDINI, Lella. Espaços educacionais e de envolvimento pessoal. In: EDWARDS, Carolyn et al. As cem linguagens da criança: A abordagem de Reggio Emilia na educação da primeira infância. Trad. Dayse Batista. Porto Alegre: Penso, 2016.

GIRARDELLO, Gilka. Imaginação: arte e ciência na infância. Pro-Posições, Campinas, v. 22, n. 2 (65), p. 75-92, maio/ago. 2011. Disponível em: <https://www.scielo.br/pdf/pp/v22n2/v22n2a07.pdf >. Acesso em: 4 out. 2020. 
GUIMARÃES, Daniela de Oliveira. Relações entre crianças e adultos no berçário de uma creche Pública na cidade do Rio de Janeiro: técnica corporais, responsividade, cuidado. Tese (Doutorado em Educação). Pontifícia Universidade Católica do Rio de Janeiro, Rio de Janeiro, 2008. Disponível em: 〈https://grupoinfoc.com.br/publicacoes/doutorado/d11.pdf〉. Acesso em: 8 dez. 2020.

HARTUNG, Pedro. Um presente a ser compartilhado: o vínculo. Instituto Alana, 2019. Disponível em: <https://alana.org.br/um-presente-a-ser-compartilhado-o-vinculo/>. Acesso em: 12 out. 2020.

KRAMER, Sônia. A infância e sua singularidade. In: BRASIL. Ministério da Educação. Ensino fundamental de nove anos: orientações para a inclusão da criança de 6 anos de idade. Brasília, DF, 2007. p. 13-23. Disponível em: <http://portal.mec.gov.br/seb/arquivos/pdf/Ensfund/ensifund9anobasefinal.pdf >. Acesso em: 9 dez. 2020.

KRENAK, Ailton. Ideias para adiar o fim do mundo. São Paulo: Companhia das Letras, 2019.

MALAGUZZI, Loris. História, idéias e filosofia básica. In: EDWARDS, C.; GANDINI, L.; FORMAN, G. As cem linguagens da criança. Porto Alegre: Artmed, 1999.

MOURA, Maria Teresa Jaguaribe Alencar de. Escola e museu de arte: uma parceria possível para a formação artística e cultural das crianças. TEIAS: Rio de Janeiro, ano 6, n 11-12, jan/dez 2005.

PIORSKI, Gandhy. Brinquedos do chão: a natureza, o imaginário e o brincar. São Paulo: Peirópolis, 2016.

ROCHA, Ruth. Nicolau tinha uma ideia. Ilustração de Mariana Massarani. 3. ed. São Paulo: Quinteto Editorial, 1998.

SAMPAIO, Rosa Maria Whitaker Ferreira Sampaio. Freinet. São Paulo: Editora Scipione, 1994. p. 117-177.

SANTOS, Boaventura de Sousa. A cruel pedagogia do vírus. Coimbra: Almedina, 2020. Ebook. Disponível em: <http://www.abennacional.org.br/site/wpcontent/uploads/2020/04/Livro_Boaventura.pdf>. Acesso em: 09 dez. 2020.

SBP. Manual de orientação da Sociedade Brasileira de Pediatria: Uso saudável de telas, tecnologias e mídias nas creches, berçários e escolas. Departamentos Científicos de Pediatria do Desenvolvimento e Comportamento e de Saúde Escolar. No 06, jun. 2019. Disponível em: <https://www.sbp.com.br/fileadmin/user_upload/21511d-MO_-

UsoSaudavel TelasTecnolMidias na SaudeEscolar.pdf>. Acesso em: 4 out. 2020.

SIMONE, Vanisse. A abordagem Reggio Emilia na Educação Infantil. Revista Contemporartes, 2020. Disponível em: <https://revistacontemporartes.com.br/2020/05/19/aabordagem-reggio-emilia-na-educacao-infantil/>. Acesso em: 7 dez. 2020. 
TIRIBA, Léa. Crianças, natureza e educação infantil. In: Reunião Anual da ANPED, 29, 2006, Caxambu: Anais GT7. Disponível em <https://anped.org.br/sites/default/files/gt072304.pdf>. Acesso em: 05 out. 2020.

VYGOTSKY, L. S. Interação entre o aprendizado e desenvolvimento. In: L. S. Vygotsky. A Formação Social da Mente. São Paulo: Martins Fontes, 1984. p. 89-103.

\footnotetext{
' Graduada em Pedagogia pela Universidade do Estado do Rio de Janeiro (UERJ). Possui especialização em Administração, Planejamento e Implementação da Educação a Distância pela Universidade Federal Fluminense (UFF). Atualmente é Técnica Universitária da UERJ, atua como professora regente de Educação Infantil e desempenha a função de mediadora pedagógica a distância do curso de Pedagogia a distância da UERJ, pelo Consórcio CEDERJ. Rio de Janeiro/BRASIL. E-mail: claudiavasconcellos1709@yahoo.com.br. ORCID https://orcid.org/0000-0002-6215-0579

ii Atua como coordenadora pedagógica de uma escola particular do Rio de Janeiro, diretora executiva de Educação e Cultura do SINPRO-Rio (Sindicato dos Professores do Rio de Janeiro e Região). É cofundadora do Movimento Articulação Infâncias e pesquisadora do Grupo de Estudos e Pesquisa "Infâncias, Tradições Ancestrais e Cultura Ambiental" (GITAKA UNIRIO). É membro do apoio pedagógico no curso de extensão Infâncias Brasileiras corpo, arte, natureza, decolonialidade (NINA-UNIRIO). Licenciada em Pedagogia pela Universidade Celso Lisboa-RJ e com pós Graduação de Psicopedagogia pela PUC Rio. Formação em Transpsicomotricidade Educacional (IFJT/UERJ). Professora de Educação Infantil e $1^{\circ}$ ano do Ensino Fundamental, há mais de 30 anos. Rio de Janeiro/BRASIL. E-mail: marta.trans@ gmail.com ORCID https://orcid.org/0000-0002-4018-9755

iii Graduada em Pedagogia pela Universidade Federal do Estado do Rio de Janeiro (UNIRIO). Atua como professora de Educação Infantil. Rio de Janeiro/BRASIL. E-mail: patyzampier@yahoo.com.br ORCID https://orcid.org/0000-0002-4488-2733
}

${ }^{\text {iv }}$ Como forma de preservar a identidade das crianças, neste artigo, usaremos letras do alfabeto para a identificação, seguida da idade delas.

v Sid, o cientista. Episodio 2 - A Lupa. Disponível em: 〈https://www.youtube.com/watch?v=EwgfG0OJqjI $>$. Acesso em: 20 jul. 2020.

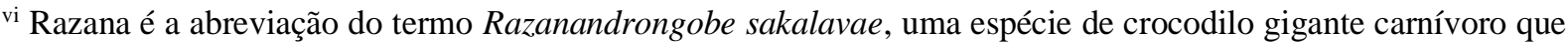
vivia no período Jurássico.

vii O National Museum of Natural History é um museu administrado pela Instituição Smithsoniana e fica localizado em Washington, D.C. nos Estados Unidos da América.

viii SMITHSONIAN, Museu Nacional de História Natural. Tour virtual. Disponível em: <https://naturalhistory.si.edu/visit/virtual-tour>. Acesso em: 30 set. 2020. 